\title{
Artikkel 2
}

Artikkel 2 Yngve Antonsen, Odd Arne Thunberg, Tom Tiller (2011). Bank advisors work between contradictory demands of control and reflective learning. Reflective Practice (accepted with minor revision). 


\section{Bank advisors work between contradictory demands of control and reflective learning}

Yngve Antonsen, Odd Arne Thunberg \& Tom Tiller (in alphabetic order)

Yngve Antonsen, PhD student in the Department of Education, Faculty of Humanities, Social

Sciences and Education, The University of Troms $\emptyset$, Norway.

Odd Arne Thunberg, PhD student in the Department of Education, Faculty of Humanities, Social Sciences and Education, The University of Troms $\varnothing$, Norway.

Tom Tiller, Professor in the Department of Education, Faculty of Humanities, Social Sciences and Education, The University of Troms $\varnothing$, Norway.

Word count, included references and tables: 6936 


\section{Abstract}

Purpose: Analysis of learning strategies in an organisation using the Balanced Scorecard based on theory about reflective learning and external constraints on learning.

Design, methodology, approach: Empirical data from a case study of a Bank comprising 40 qualitative interviews, eight two-day focus groups and attendance at 35 learning activities. Grounded theory was used to understand how the organisational strategy and the understanding of employees about learning activities at work were consistent or contradictory. Additionally we analysed 2284 registered learning activities recorded by Bank employees on a Balanced Scorecard.

Findings: The top-down strategy for learning - "Best Customer Practice" - recording information about and accounting for learning, when combined with a new institutional demand for authorization and training - has a controlling function that contradicts the organisation's own rhetoric about promoting reflective learning among the employees.

Research implications: Top-down learning strategies reduce the employees' possibilities to contribute with reflective learning in organisational development.

Practical: Employees are motivated by feedback from their customers.

Social: Learning strategies in a financial organisation promote top-management control and constraint the employees' possibilities to contribute with quality assurance and new ideas about their work.

Originality / value: Reveals how top-management control influences advisors' learning in a financial organisation.

Word count abstract: 198 


\section{Introduction}

Theories about learning and change in organisations emphasize learning through reflection as centrally important for improving employees' work performance and customer service (Boud, Cressey \& Docherty 2006). Schön's theory (1991) suggests that when employees learn from situations such as customer service this learning can be seen as an interplay between the actual meeting, the "action", reflection on the action, and an analysis of new possibilities. Reflective learning involves thinking critically about the situation and: "Is identified with a potential for change, as it questions key variables instead of just accepting and repeating a given body of knowledge" (Jarvis, Halford \& Griffin 2003, p. 70). This involves that employees critically assess opinions, theories and practice from various positions and perspectives in order to assure quality (Dewey 1991). Such processes may give rise to new alternatives to established organisational routines based on a more dynamic relationship between routines and reflection. Fenwicks (2008) review criticize workplace learning research because it fails to pay critical attention to the importance of the power of management in promoting reflective learning in organisations.

Røvik's (2007) study reveals how new management systems, and especially the Balanced Scorecard (Kaplan \& Norton 1996), have become prescriptions for shaping modern organisations to pursue efficiency, and are applied in many organisations at the same time. The Scorecard is designed so that top-managers develop a pre-defined top-down strategic plan that directly influences how work tasks, both simple and complex, are performed and rewarded. Research on the use of the Balanced Scorecard reveals that this system strengthens senior management control by micro-managing employees' work tasks in detail (Paranjape, Rossiter \& Pantano 2006). Such top-down organising of work tasks and methods are criticised because they decrease employees' opportunity to influence and participate in decisions about their own work (Voelpel, Leibold \& Eckhoff 2006). Hierarchies in organisations tends to weaken opportunities for employees to reflect critically in order to improve their current practice (Argyris \& Schön 1996). Nilsen's (2007) study of a bank proposes that the use of the Balanced Scorecard and 'top-down strategies for learning' are tools for promoting employees obedience to authority. The business tradition of basing objectives on the volume of sales and services has been transferred to the financial sector and to banks. This contrasts sharply with the principles of reflective learning that serves to promote human growth by allowing learners to make personal choices (Jarvis, Halford \& Griffin 2003). 
In banking organisations, central and local rules and credit routines are necessarily requirements for handling customers and assets. Advisors in banks all over the world have been blamed for greed during the financial crisis of 2008. The mandatory New Norwegian authorization initiative for advisors aims to ensure high-quality customer service by raising knowledge and introducing ethical standards for customer relations and meetings. However, this study questions how top-down management with the use of the Balanced Scorecard and new institutional demands influences the practice of reflective learning among advisors who provide customer service.

This case study is part of a four year research project on workplace learning in a traditional bank with more than 700 employees located in more than 50 departments of various sizes in Norway. The bank is highly driven, with very good profits and a top international 'A' Fitch Rating. The management system the Balanced Scorecard has been used as a recipe for maximizing the bank's profit since 2002. The senior management learning strategy aiming to improve customer service involves obligatory learning activities where two or more advisors share their knowledge and experience. In order to achieve a bonus, 6 learning sessions per month each of 30 minutes had to be registered by advisors in an indicator in the Balanced Scorecard. The written strategy reveals that these learning initiatives should not contain instruction, lectures or information. These initiatives aimed to increase employees' reflective learning in the bank.

\section{Reflective learning from customer service}

Schön (1991) distinguishes between the expert and the reflective practitioner. Experts are expected to know the answers even in uncertain situations. They signal that they know more than customers as a result of their expertise and ability to distance themselves from problems. In the professional meetings such experts are polite and sympathetic to clients but expect humility from the customers. The reflective practitioner however does not necessary have all the answers in uncertain situations. In meetings between the reflective practitioner and customers they both may contribute information and knowledge and have to build mutual respect of each others' knowledge through the practitioner's facilitation of the meeting. In order to achieve high-quality customer meetings, reflective practitioners must also possess integrity and freedom that empowers them to solve problems that arise (Ellström 2001). 
Hochschilds' empirical study (2003) confirms that face-to-face situations comprise the most significant learning experience for all involved. In situations where employees receive positive confirmation from customers, this can form a particularly solid basis for reflective learning. The quality of human encounters is crucial for reflective learning, motivation, wellbeing and self-image. Schön (1991) claims that reflection may contribute to self-knowledge and consciousness-raising about one's own knowledge. Ellström (2001) argues that such metacognitive knowledge is developed when the individual is aware of his or her limitations and strengths. Reflective work promotes knowledge, skills, self-confidence and motivation among individuals. Edmondson's study (1999) from learning in teams emphasizes psychological safety, trust and responsibility between members as the most important factors for facilitating critical questioning and reflection. Giving employees the opportunity for codetermination at work appears to be important in promoting learning among individuals and organisations.

Nonaka \& Takeuchi (1995) express the importance of using reflective learning to identify and conceptualize tacit knowledge in organisations. For example, when the employees' own tacit knowledge about advising customers is articulated and conceptualized, it can be transferred to other colleagues. Such learning from experience is not an entirely simple process because work situations vary and are difficult to identify and analyse during a busy working life. Through distancing ourselves from the immediacy of practice, we can discover individual and collective experiences, allowing us to regulate, correct and change our practice. Varied and diverse reflection on practice can help prevent a uniform approach to task performance (Michel \& Wortham 2009). Thus Giddens (1990) argues that reflection may contribute to creativity and innovation in working life, which is important in the competition for customers in a rapidly changing world.

An organisational strategy that promotes reflective learning and communication between customers, employees and senior management is crucial for quality assurance. However, individual learning and reflection alone are not enough to develop organisations. If the strategic learning initiatives in practice do not support learning from customer relations, then reflective learning from experience will falter. 


\section{Possible constraints for reflective learning}

In working life when the pressure for efficiency increases, time for employees' learning is eroded (Giddens 1990; Senge 1999). Financial organisations in particular are working in a global market where the demands for profit have been increased also during the financial crisis of 2008 (Krugman 2009). Hackman and Wageman (2005) argue that three combined key factors underpin team (in our case the team comprises advisors and office manager) performance of work tasks:

1. The level of effort from the collective team to solve the work task.

2. The suitability of the team's work methods or performance strategies for the tasks.

3. The sum and utilisation of knowledge and skills that contribute to the team's execution of the task:

Table 1: External Constraints on Team Leader Impact

\begin{tabular}{|l|l|l|}
\hline $\begin{array}{l}\text { Performance } \\
\text { Process }\end{array}$ & Team - Level Constraints & $\begin{array}{l}\text { Contextual } \\
\text { Constraints }\end{array}$ \\
\hline Effort & Work inputs are under external control & $\begin{array}{l}\text { Noble collective } \\
\text { purposes }\end{array}$ \\
\hline $\begin{array}{l}\text { Performance } \\
\text { strategy }\end{array}$ & $\begin{array}{l}\text { Performance operations are organizationally or } \\
\text { technologically determined }\end{array}$ & $\begin{array}{l}\text { Strong institutional } \\
\text { forces }\end{array}$ \\
\hline $\begin{array}{l}\text { Knowledge and } \\
\text { skill }\end{array}$ & Work activities are simple and predictable & $\begin{array}{l}\text { Skewed labour } \\
\text { market }\end{array}$ \\
\hline
\end{tabular}

(Hackman \& Wageman 2005)

Hackman \& Wageman (2005, p. 41) further argue that team level constraints limit office manager and employees' opportunities to influence their own daily practice. For example, having few potential customers, or lacking relevant equipment, may hinder efforts by employees to increase sales.

Also performance strategies that use procedures, manual and technology to specify in detail the methods to be used in work tasks, hinder the potential of office managers and employees to influence and improve how work tasks are performed. In a review article Paranjape, Rossiter and Pantano (2006) explain that the Balanced Scorecard management system aims to increase efficiency through stronger senior management control. It is a top-down strategy guided by a rationalist economic perspective. The Balanced Scorecard is designed to convert 
the organisation's strategic plan into effectively performed and rewarded work tasks (Kaplan \& Norton 1996) by counting and controlling the implementation of all work tasks and sales demands designed by management (Nilsen 2007). The senior managers have the power to define and make demands to which others must choose whether or not to conform. Intangible and tacit work practices are easily overlooked in organisations when management systems and models of economic organisations assume strong control over information, meetings and action (Nørreklit 2003). It is easy to conclude that using the Balanced Scorecard creates more operational rules, procedures and rigidity (Paranjape, Rossiter \& Pantano 2006).

As senior managers really matter in promoting reflective learning, A destructive leader may hinder learning in organisation, and even well-regarded leaders are not always able to improve and affect employees' and office managers' work (Hackman \& Wageman 2005). Mintzberg, Ahlstrand \& Lampel (1998) argue that the most important work of senior managers is strategic development because it directs and focuses the contribution of employees and office managers to organisational production and development. Senior managers have central responsibility for organisational learning, that is implementing and change in organisational strategies and routines (Argyris \& Schön 1996).

On the other hand, when the senior management using the Balanced Scorecard decides to change manuals that detail work tasks, employees' learning may also be seen as matter of making only a simple adjustment to regulate performance (Argyris \& Schön 1996). Participants may become disillusioned when administration and organisational strategies obstruct development. Critical participants who suggest new solutions and improvements in their organisation may be seen as disloyal to management. Without room for such criticism, they may find themselves vulnerable or isolated, especially if only a few employees are critical of operations or power (Hackman \& Wageman 2005).

Hackmann and Wagemans (2005) table further emhasise that three contextual constraints influence team performance in organisations. 1. Organisations have a main noble purpose that motivate members to work hard and increase their effort to help other people independently of managers instructions. Bank advisors give financial help to customers by means of loans, insurance and savings. 2. Strong institutional laws and regulations specify how organisations should operate, and this regulate how bank advisors should perform their tasks to prevent fraud and economic crime. 3. The labour market influences how banks promote competence 
and learning among advisors and office managers. As do the bank provide reflective learning occasions for employees to learn from each other? Argyris and Schön (1996) argue that reflective learning, without opportunities for influence, provides learning gains, neither for employee nor organisation. Research indicates that the management must aid reflection on practice and must give up power if employees are to exercise influence (Michel \& Wortham 2009). Vince argues (2002) that inclusion and integration are keys to enhanced collaborative critical reflection, where everybody participates in the process even though they have different functions in the organisation.

\section{Research method}

The qualitative materials for this study were collected and analyzed over a 30-month period. Thirty two customer advisors and eight office managers were interviewed. These informants of various ages, length of service and both genders were randomly selected from five different branches of the bank. In these 30-60 minute interviews we asked open-ended questions in order to have a constructive dialogue. The use of semi-structured interviews allowed the researcher to let the interview flow and follow up leads and information from the advisors and office managers. This enabled us to explore the learning of customers, colleagues and the bank in general. Two researchers attended, both separately and together, 35 learning activities in five departments over a two-year period. To enhance the empirical evidence eight, two-day focus groups were conducted in which three researchers and an average of ten office managers volunteered to discuss and analyse the bank's learning challenges (Wilkinson 2004). In general, a good level of trust and interaction between office managers, advisors and researchers led to a rich set of empirical data. All the data were transcribed, in addition to written summaries from 25 learning activities. We used the data analysis software NVivo 8 (Bazeley 2007) with the purpose of categorizing grounded data to understand how the employees understood, agreed and differed about strategies and customer learning in the bank (Glaser \& Strauss 1967). In the resulting varied material about learning, all similar statements were first openly coded into categories based on the data. Thereafter these categories were employed, clarified and confirmed through use of field notes, memo writing and discussions between researchers. The number of categories increased by building "trees" of categories to capture order in the data (Bazeley 2007). The analysis reveals four strategic and institutional learning initiatives that were used to develop customer service by the bank over a three year period: "Best Customer Practice", information and accounting of learning activities, 
authorization, and training. Advisors and office managers valued learning from customer relations as most important for improving their own work tasks. This contradicted their statements about the senior management's strategic learning initiatives.

We used an overview of all employees' recorded learning activities completed from January 2008 to June 2009, a total of 2284 entries. These records gave us systematic information about what kinds of learning activities are most salient in the organisation. Some caveats about this overview process are needed: the high amount of short and possibly imprecise descriptions contained in the entries might produce a potential self-reporting bias; employees may have copied each others' entries while completing the required records even if they had learned different content; the records also lack a precise timetable; different learning content is often summed up in only one recorded learning activity, and duplicated entries are also evident; seven percent of the original material lacked descriptions and was taken out of the analysis; and finally, there may have been unrecorded learning activities. The strength of the analytical work is that two researchers took part both in the data collection in different levels of the organisation and in the categorization (researcher triangulation). Also the inter-rater reliability is confirmed as the researchers both found consensus between both the quantitative material and the recorded entries.

\section{The bank's priorities and context}

The rhetoric of the bank in this case study corresponds to modern discourses of working life and concepts such as 'learning', 'team work', 'learning organisation', are evident in its strategic planning documents. "The bank is a learning organisation, which actively develops employee's knowledge, skills and attitudes to solve the customers' requirements" (Annual Report 2007).

As early as in 1992, the bank began to focus on building long-term high-quality customer relations. The stated vision and ambition in 2009 was to be "close to and competent for" all customers, and thus to provide the best advice based on local accessibility, relations and knowledge. But surveys of customer satisfaction indicate perceptions that competence is less than in competing banks. The challenge for the past 17 years has been to strengthen customer relations, at a time when on-line banking and automated teller machines have reduced the need for face-to-face contact between advisors and customers. Modern banking has become 
more efficient and has reduced the need for expensive face-to-face transactions (Flohr Nielsen \& Preuthun Pedersen 2003; Nilsen 2007). When orders and requests from the customers are carried out automatically, both contact and costs are reduced.

This bank, like other banks, is organised hierarchically and characterized by top-down management, as all our respondents confirmed in the analysis.

The hierarchy in a bank is strong. If the senior management asks for a report from everybody within a week, all will provide one! (Office manager in a focus group)

Our analysis reveals that senior management emphasises the need for increased efficiency, change and adaptation to the market. In a very hectic round of everyday customer work, employers and managers are challenged to increase profitability through a focus on sales, advice, control, reports, prognoses and information. These new demands, in addition to lack of personnel, increase stress among the advisors from all the five branches in the bank. A common quote from our interviews is:

We have had large level of stress over time because of lack of personnel (Advisor in interview).

This finding about the advisors' lack of time was also confirmed by all office managers in the focus groups.

\section{The voice of the advisor: Learning from customer contact and the constraints of credit routines}

The advisors' most important source of motivation and energy for learning comes from customer contact. All advisors emphasized in interviews that good customer relations are important for well-being, job satisfaction and professional pride. The advisors are aware that they are seen as significant in the life of the customers.

I feel that I can contribute. I like having people around. No two customer meetings are the same, and this is why I have stuck it out for so long. I simply don't take sick leave, because I 
feel responsibility for the customers. The customers are loyal to me, and I am loyal to them (Advisor in interview).

Positive feedback from customers usually comes verbally, directly to the advisors or to the management. But feedback from customers may also come in the form of visible actions such as sending flowers and candy. On such occasions, the positive message is also spread to colleagues through a symbolic gift which is left on the desk, or by means of discussion in the lunch room.

All interviewed advisors and office managers emphasized that knowledge of how to advise is developed through experience. The advisors learn sales techniques and relationship-building in practice, through customer contact. Being able to see each individual customer and to find good, flexible solutions based on the needs of the customer and the requirements of the bank, gives the advisor a sense of competence and of making a difference in the customer's life. At a time when products of banks are becoming more and more similar and competition intensifies, advisors focus on the importance of this knowledge gained from customer contact. A majority of advisors also emphasized that flexibility in adapting solutions to problems provides a competitive advantage for the bank. This scope for influence and action has been an important factor for working in the bank.

Decisions of greatest significance are made by senior management to maximize profit and reduce losses. The interviewed advisors, who knew their customers well, revealed that they had to adhere increasingly to new credit or sales instructions and felt squeezed between customer loyalty and loyalty to the system.

You have customers that make one million kroner a year. They have huge cash assets, but they may have problems when the interest rate increases because of high expenditure. The simulated figures do not reveal inter-human aspects, such as how you are as a person and your willingness to pay your debts. But customers with a low income and a strong willingness to pay may be more valuable for the bank in the long term (Advisor in interview).

New complicated credit manuals were sometimes unclear and vague and with the result that customer credit applications may be rejected when advisors present them to the management. It is difficult for an advisor who knows the customer well to reject him or her, after having 
initially sent positive signals to the customer who thus expected to be granted a loan. Being at the same time "close to and competent for" customers created a problem if the advisor became too close to the customer and as a consequence lacked critical distance when offering loans. A quote reveals a similar dilemma for advisors hunting for new customers:

We are requested to be aggressive in seeking new customers, but it is a problem when we have such strong internal regulations. You cannot phone a potentially new customer, get a positive response and then reject the customer because he does not suddenly satisfy the internal rules" (Advisor in interview).

However, the credit routine system and the distance between senior management and customers eased the pressure on advisors and office managers who did not have to make the unpopular decisions. As a consequence this distance may cloud the senior management's knowledge of the advisors' customer competence, people skills, and detailed knowledge.

\section{The bank's strategic learning initiatives}

The four strategic and institutional learning initiatives for improved customer service are: "Best Customer Practice", information and accounting of learning activities, authorization, and training.

\section{a) Best Customer Practice}

The "Best Customer Practice" is a manual about how advisors should prepare, conduct and review their customer meetings. In order to gain an overview of customer needs, meetings are planned in advance. The customer is then offered several products such as pension plans, savings targets, lifetime loans and insurance. Senior management ordered that, from 2006, everybody in the bank had to use this best customer practice with the aim of selling as many products as possible to each individual customer. The bank wants all advisors to complete two planned meetings with customers per day and record this in the Balanced Scorecard. The control initiative is then measured statistically in the Scorecard and followed up by senior management.

In order to achieve these aims and organise time and information optimally, the bank wishes to change both advisor and customer habits. The advisors have to teach the customers to book 
an appointment. This turned out to be a difficult transition. One department, for example, put a wooden pallet in front of the advisors' offices with a large sign saying "Remember to book an appointment at the counter". On the very first morning, the first customer sneaked around the obstacle and barged into the advisor's office. The habits and demands for drop-in service both from customers and advisors are difficult to change. As a result an advisor reported the need to use time in the team to discuss and reflect on how the advisors could use the best customer practice better in the everyday work:

We should use more time on the work practices, how it is smart to work. We are too statistically controlled of using the BSC, instead of focusing on best customer practice. It is annoying, but the senior management does not see this (advisor in interview).

As a part of the strategic plan, all new advisors have practiced "Best Customer Practice" in a three-month introduction course. Our data reveal that the practice is a useful tool for the majority of new advisors with no previous experience and no portfolio. New advisors implement "Best Customer Practice" with greater ease than do experienced advisors. Nevertheless experienced advisors are also using the "Best Customer Practice" with positive outcomes:

If you can be so structured then you have a great working day. I am very engaged in Best Customer Practice, I have used it and it has been a new world for me (Advisor in interview).

These positive experiences are however seldom collectively reflected upon. In practice the established routines of many experienced advisors connected to their large portfolios still influence many of their meetings with customers. By serving drop-in customers, as they always have been doing, the working day is fragmented and there is a lack of time and few opportunities for gathering information and preparing broad sales. When many of the experienced advisors are not following the process in practice this means that the senior management's strategic initiatives are challenged. 
We do not take the time to implement new procedures. Best Customer Practice is a good example of a huge mistake. Even now at the end of 2009, still not everybody is using this tool (Office manager in a meeting).

Best Customer Practice is particularly undermined in cases where experienced advisors continue as before, and sell more than the new advisors who loyally adhere to the new strategic plan. Their explanation is that sales of several products at the same time may paralyze the customer in making decisions to buy. Many advisors therefore, based on their own experience, adopt a longer-term perspective in offering their products. In addition, a large and solid portfolio of regularly customers' challenges experienced advisors time to use the "Best Customer Practice".

\section{b) Information and accounting for learning activities}

The analysis of the 2284 recorded learning activities, reveal that office management gave detailed information in $89 \%$ of the recorded activities. The information comprised four main topics: product presentations and manuals; summary of the Balanced Scorecard; sales and financial results; and new rules for processing loans (Antonsen, Thunberg \& Tiller 2010). In reality, the learning activities are about spreading organisationally- or technologicallydetermined performance operations and institutional forces. The idea behind recording the activities was to increase the volume of learning and call attention to learning initiatives. Management and advisors see knowledge of products and regulations as an important basis for good customer contact. However, the strong focus on information and accountability took a lot of the advisors' time to update records of their own progress in meeting the objectives. One advisor described the increasing measuring in the Scorecard as a problem:

\footnotetext{
We don't think it should be necessary to use so much time on registering our activities. Senior management is designing measuring indicators without knowledge about advising, and advisors say it is not so easy to implement this frequent measuring in practice (Advisor in interview).
}

There has traditionally been a culture of measurement for accountability in the bank. However, measuring had the side effect of lessening the focus on qualitatively good customer service while increasing the emphasis on the quantity of sales activities that result in a bonus. 
Thirteen percent of all learning activities recorded consist only of summaries of the results in the Balanced Scorecard. Our data about the presentations of the monthly BSC results in departments revealed that the numbers are usually reviewed with the comments "this is good, satisfactory and here you have to improve". The advisors did not participate in deciding the targets, neither did they reflect about how to improve the results. As a consequence, information and the 'recording of registered learning' has been identified as 'learning', rather than actual improvements based on reflective learning. A focus group session discussed this topic and concluded that one-sided accounting and a too high a focus on presentations and products results in a problem for learning:

Competence in relationships is not on the agenda when it comes to learning, and is not represented to the same extent as financial competence. It is competence in relationships which is our livelihood (Office manager in focus group).

In the learning activities there is negligible registration of the intended focus areas of 'knowledge' and 'experience sharing'. There may, however, be under-registration of such learning as our interviews suggest that individual departments also focus on cooperation and sharing knowledge from experience, even though this has not been registered. Another explanation may be that among advisors, reflective learning from performing everyday tasks is hard to describe and therefore hard to measure. Because of the financial crisis of 2008 the bonus for registered learning was abandoned. The advisors started focusing less on accounting for learning activities and more on the new requirements for authorization.

\section{c) Authorization}

Advisors in Norwegian banks now have to gain a 'pass' and become authorized in order to keep their responsibilities. A theoretical and practical test must be passed. The theoretical content consists of personal economy, macroeconomics, financial markets, methods, portfolio composition, product groups, attitudes, ethics, the advisory practice, and rules and regulations. Testing of theoretical knowledge is completed via the Internet. Practical factual knowledge is examined by means of role play. Here the advisors are assessed as 'pass' or 'fail' by a jury consisting of a office manager and a bank employed examiner. Thus, that the practical authorization examination is done internally this may strengthen the bank's control of and authority over the advisors. 
The financial business sector is behind this institutional qualification demand. The financial crisis made the initiative particularly relevant and accelerated its implementation, resulting in it becoming obligatory on January 1, 2009. All advisors must learn to ask obligatory ethical questions to make sure that the customer has understood which products he is buying, and thus prevent over-aggressive sales of so-called high-risk savings products such as hedge funds.

One change is to reveal the needs of the customers. If the customer does not have a car, we should not sell him car insurance just to win a trip to Manchester! (Office manager in a meeting).

Our data reveal that the most experienced advisors have the greatest challenge in meeting the requirements, because they lack the theoretical basis for understanding the complex topic of macroeconomics. The theoretically educated, who have been selling high-risk saving products to the greatest extent, are best equipped for meeting the requirements. Ninety percent of advisors in our case will probably never sell such products and are now spending much time during working hours and in their spare time studying for the authorization. Stress among the majority of advisors increased considerably when the two first advisors failed the practical test. This focus on individual authorization decreases time for reflective learning.

\section{d) Training sessions}

In order to pass the practical test to become authorized and increase sales in meetings with customers, the advisors need training sessions. Through role play as advisors, customers and observers, they regularly switch roles and practice techniques for increasing sales while using the ethical questions. Training on "Best Customer Practice" also means practising how to phone each other by asking the important sales questions to customers, and they also simulate customer meetings using problems that they have experienced. All the advisors testify that such training methods create security and facilitate the sharing of experience. But some of our informants also point out that sales training that is limited to simplified cases may be problematic in developing long-term customer relations. 
If you push a product on the customer, you will not keep him for life. I wish to see an assertive drive in the behaviour of advisors. But there should not be a drive to sell life insurance. There should be a drive to get the customers to see for themselves what happens if they do not have life insurance. This is the inherent driving force. Your objective is to get the customer to understand their own needs. (Office manager in a meeting).

The informants say that there is not time for critical reflective learning before, during, or after training sessions to improve sales and ethical questions. In dialogues between the advisors and the customers, the essential point is that the customers themselves can define their needs and wishes. The challenge is whether this can be promoted mainly through training routines or whether reflective learning is needed to improve the employees' competence and long-term customer relations.

\section{Discussion}

We argue that the idea of setting aside time for employees' learning is a good strategy especially in financial organisations. However our empirical findings indicate that advisors are faced by an overload of information and demands for accountability from senior management. The Balanced Scorecards use of a "Best Customer Practice" strategy, along with the authorization initiative and the training are all designed to influence and control the objectives and the methods used by advisors in carrying out their responsibilities. Customer regard for the advisor and the building of trust are in danger of being choked by these new instrumental routines. Time for individual and collective reflective learning from customer relations is constrained by bank and institutional initiatives that emphasize control and security. The advisors' individual potential for reflective learning, influence and motivation decreases when work processes are turned into non-reflective routines and when both internal administrative and external documentation requirements are increased to protect the customers' economic security. This finding is supported by a recent study confirming that employees are facing increased demands to keep their skills up-to-date, in parallel with attending to customer work (Goldman et al. 2009).

A top-down strategy that is too narrowly focused limits employees' possibilities to contribute with quality assurance about the function of routines, which limits new ideas for change and 
development. When the internal learning strategies merge with the external institutional forces the employees' possibilities for reflective learning are constrained as seen in table 2:

Table 2: Constraints on reflective learning:

\begin{tabular}{|c|c|c|}
\hline $\begin{array}{l}\text { Performance } \\
\text { Process }\end{array}$ & $\begin{array}{l}\text { Team - Level Constraints on } \\
\text { reflective learning }\end{array}$ & $\begin{array}{l}\text { Contextual Constraints on } \\
\text { reflective learning }\end{array}$ \\
\hline Effort & $\begin{array}{l}\text { The bank's ambition: "close to and } \\
\text { competent for" all customers }\end{array}$ & Customer demands \\
\hline $\begin{array}{l}\text { Performance } \\
\text { strategy }\end{array}$ & $\begin{array}{l}\text { Balanced Scorecard } \\
\text { "Best Customer Practice" }\end{array}$ & $\begin{array}{l}\text { Authorization } \\
\text { Credit Routines }\end{array}$ \\
\hline $\begin{array}{l}\text { Knowledge } \\
\text { and skill }\end{array}$ & $\begin{array}{l}\text { Training } \\
\text { Product knowledge }\end{array}$ & \\
\hline
\end{tabular}

The bank wishes to use the Balanced Scorecard and the "Best Customer Practice" to streamline and standardize its products and services in order to achieve higher sales results. The vision of being "close to and competent for" the customer in all customer relations creates possibilities for reflection on how learning can be more strongly derived from meetings with customers. The experienced advisors limit the amount of products they offer the customers in order to avoid decision-resistance by the customers. This quiet defiance of the "Best Customer Practice" may help to explain the financial success of the bank. The tacit knowledge of the advisors derived from customer meetings seems to be underestimated in the overall learning strategy of the bank. This learning should contribute to making advisors' "close to and competent for" customers and high-quality meetings with customers also promote job satisfaction. Reflection among the employees about using the Best Customer Practice could possibly develop and increase the use of the process in the organisation. The Balanced Scorecards' focus and requirements for measuring, efficiency and tempo may have a constraining effect by using possible extra spare time for reflection on information and unreflective measurement. Such information does not develop the advisor-customer relationship and may damage the bank's competitive advantage in the long term.

Highlighting only the visible overt actions in the Balance Scorecard means that tacit knowledge and reflective learning among employees are not recognised or valued in the development of the organisation. In the Balanced Scorecard both invisible assets and reflective learning are difficult to measure and record. Another problem is that the data 
recorded will not include frustrations or new possibilities for action that are not followed up. As a consequence, such intangible factors are not communicated to the senior management, as also seen in Elgs (2009) study, and thus the potential for organisational learning are diminished (Argyris \& Schön 1996).

The noble contextual demands of a bank by giving customers financial support contains ethical challenges to the advisor that must be coped with. New authorization and credit routines shall protect both banks and customers. The demands for internal control, regulations and information are increasing rapidly in financial organisations at the same time as they are challenged by owners and government to increase revenues. Senior management implements and controls the strategies. This creates a dilemma for advisors who are encouraged by senior management to increase the sales of products to customers at the same time as they should care for the liquidity of the customers. Advisors simultaneously take the responsibility and the blame for handling customers and revised performance criteria. In other words, they are asked to use the accelerator and the brakes at the same time!

\section{Conclusion}

Reflective learning among employees is valued as essential for long-term development in organisations (Boud, Cressey \& Docherty 2006). However new management systems as the Balanced Scorecard are introduced with the purpose of making organisations function more effectively using top-down control. We asked how the use of the Balanced Scorecard and new institutional demands influences the practice of reflective learning among advisors who provide customer service. Our findings show that the senior management's learning initiatives in fact are focused on the organisational control rather than reflective learning. Advisors use their time to learn detailed product knowledge and work instructions while senior managers organise this process. This contradicts the bank's written strategic plan for learning that advocates reflective learning for all advisors. The four strategic learning initiatives outlined above also contradict advisors' statements about how they learn customer service by means of reflective practice, a form of learning that they claim offers high value for the organisation. Our findings show that rhetoric about reflective learning is not substantially realised in implementing the bank's learning strategies, despite advisors valuing such learning as a means of improving their practice. 
The four strategic learning initiatives of the bank explain how advisors have to face dilemmas concerning sales and control work resulting from bank and external authorization requirements. As a result, the time available and the opportunities for individual and collective reflective learning are limited. The impact of the training, authorization and information lead advisors to become, in Schön's (1991) terminology, 'experts' rather than reflective practitioners. The learning initiatives offer the advisors few opportunities to participate in and influence policy-making, strategic planning, objective-setting and work tasks. The top-down management strategies thus contradict current theories of workplace learning which emphasize development of employees through participation and empowerment. The strengthening of organisational control may not be the senior management's intention. If this is so, a critical question is whether the learning initiatives become manipulative because they control activities (Illich 1973). Our analysis reveals that more research is needed about how the use of the Balanced Scorecard and top-down learning strategies emphasise control and decrease reflective learning. Our case study suggests that using advisors as scapegoats in the current financial crisis should be re-evaluated. Ideally learning strategies that include quality assurance from employees' reflective learning may help prevent new financial crisis.

\section{References}

Antonsen, Y, Thunberg, OA \& Tiller, T 2010, 'Adaptive learning and reduced cognitive uncertainty in a financial organization', Journal of workplace learning, vol. 22, no. 8, pp. 47588 .

Argyris, C \& Schön, DA 1996, Organizational Learning II: Theory, method, and practice, Addison-Wesley series on organizational development, Addison-Wesley, Reading, Mass.

Bazeley, P 2007, Qualitative Data Analysis with NVivo, Second edn, Sage Publications, London.

Boud, D, Cressey, P \& Docherty, P 2006, Productive reflection at work - Learning for changing organizations, Routledge, London.

Dewey, J 1991, How We Think, Promethus Books, N.Y.

Edmondson, A 1999, 'Psychological Safety and learning behavior in work teams', Administrative Science quarterly, vol. 44, no. 2, pp. 350-83.

Elg, M 2009, 'Vilken betydelse har mätetal for ledarskapet i en teamorganiserad verksamhet?', in P-E Ellström \& H Kock (eds), Mot ett förändrat ledarskap?: Om chefers arbete i team- och processorganiserad verksamhet. Studentlitteratur, Linköping. 
Ellström, P-E 2001, 'Integrating learning and work: Problems and Prospects', Human Resource Development Quarterly, vol. 12, no. 4, pp. 421-35.

Fenwick, T 2008, 'Understanding relations of individual collective learning in work: A review of research ', Management Learning, vol. 2008, no. 39, pp. 227- 43.

Flohr Nielsen, J \& Preuthun Pedersen, C 2003, 'The consequences and limits of empowerment in financial services', Scandinavian journal of management, vol. 19, pp. 63 - 83.

Giddens, A 1990, The consequences of modernity, Polity Press, Cambridge.

Glaser, B \& Strauss, AL 1967, The discovery of grounded theory: Strategies for qualitative research, Aldine, Chicago.

Goldman, E, Plack, M, Roche, C, Smith, J \& Catherine, T 2009, 'Learning in a chaotic environment', Journal of workplace learning, vol. 21, no. 7.

Hackman, JR \& Wageman, R 2005, 'When and how team leaders matter', in B Staw \& R Kramer (eds), Research in Organizational Behavior, Elsevier, JAI Press, vol. 26, pp. 37-74.

Hochschild, AR 2003, The Managed Heart: Commercialization of Human Feeling, 20th anniversary edn, University of California Press, Berkeley, Calif.

Illich, I 1973, Tools for conviviality

Calder \& Boyars, London.

Jarvis, P, Halford, J \& Griffin, C 2003, The Theory and Practice of Learning, Kogan Page, London.

Kaplan, RS \& Norton, DP 1996, The Balanced Scorecard - Translating strategy into action, Harvard Business School Press, Boston, Mass.

Krugman, P 2009, 'How could the economist take it so wrong', New York Times, 2. October.

Michel, A \& Wortham, S 2009, Bullish on Uncertainty. How organizational cultures transform participants, Cambridge university press, New York.

Mintzberg, H, Ahlstrand, B \& Lampel, J 1998, Strategy Safari - A guided tour through the wilds of strategic management. , The Free Press, New York.

Nilsen, EA 2007, 'Oversettelsens mikroprosesser om å forstå møtet mellom en global idé og lokal praksis som dekontekstualisering, kontekstualisering og nettverksbygging', Doctor Rerum Politicarum thesis, Universitetet i Troms $\emptyset$

Nonaka, I \& Takeuchi, H 1995, The knowledge-creating company: How Japanese companies create the dynamics of innovation, Oxford University Press, New York.

Nørreklit, H 2003, 'The BSC: What is the score? A rhetorical analysis of the BSC', Accounting, Organizations and Society, vol. 28, pp. 591-619. 
Paranjape, B, Rossiter, M \& Pantano, V 2006, 'Performance measurement systems: Successes, failures and future - a review', Measuring Business Excellence, vol. 10, no. 3, pp. 4-14.

Røvik, KA 2007, Trender og translasjoner ideer som former det 21. århundrets organisasjon, Universitetsforlaget, Oslo.

Schön, DA 1991, The reflective practitioner - How professionals think in action, Ashgate, London.

Senge, PM 1999, The Dance of change: The challenges of sustaining momentum in learning organizations, Currency/Doubleday, New York.

Vince, R 2002, 'Organizing reflection', Management Learning, vol. 2002, no. 33, pp. 63-78.

Voelpel, SC, Leibold, M \& Eckhoff, RA 2006, 'The tyranny of the BSC in the innovation economy', Journal of Intellectual Capital, vol. 7 no. 1, pp. 43-60.

Wilkinson, S 2004, 'Focus group research', in D Silverman (ed.), Qualitative Research: Theory, Method and Practice, Sage, London, pp. 177-99. 